\title{
IS CROATIAN LEGISLATOR REDEFINING THE NOTION OF THE COURT: ANALYSIS FROM THE PERSPECTIVE OF THE CONVENTION LAW
}

\author{
Sanja Grbić, PhD, Assistant Professor \\ University of Rijeka, Faculty of Law \\ Hahlić 6, Rijeka, Croatia \\ sgrbic@pravri.hr
}

\author{
Dejan Bodul, PhD, Assistant Professor \\ University of Rijeka, Faculty of Law \\ Hahlić 6, Rijeka, Croatia \\ dbodul@pravri.hr
}

\begin{abstract}
The important doctrine in the case of the law of European Court of Human Rights (ECHR) is a "wide margin of appreciation" of the Member States when they take legislative or judicial actions. Moreover, national authorities are best acquainted with their regulations as well as other circumstances relevant to the adoption of specific laws. Therefore, they must assess which legal solution is the most appropriate. This is an advantage enjoyed by the national states, but they also have the responsibility for choosing the most appropriate legal solution. Therefore, legal disputes over the role of Judicial Advisors in simplified consumer bankruptcy procedure and enforcement procedure (according to the Draft of Enforcement Act) as persons conducting the procedure and persons obliged to render a decision, need to be analysed from the perspective of the standard "court established by law" according to Article 6 of the European Convention for the Protection of Human Rights and Fundamental Freedoms and Art. 29, 115 and 118 of the Constitution of the Republic of Croatia.
\end{abstract}

Keywords: reform, simplified consumer bankruptcy procedure, enforcement procedure (Draft), Judicial Advisors.

\section{METHODOLOGY}

The complexity of the thesis and set tasks conditioned the choice of methods. Thus, the methodology used includes the study of domestic and foreign literature, appropriate legal regulations as well as the analysis of domestic and foreign case study. This paper also analyses the case study of the European Court of Human Rights (ECHR) in proceedings according to Art. 6 (Right to a fair trial), since we assume that this information plays the key role in understanding of the issue 
concerned. Legislator, to reduce many unresolved cases and increase the efficiency of the judiciary, made various attempts to minimize work overload of the judges. Therefore, this research is going to closely examine the justification of delegating the right to conduct the proceedings and render the decisions to a Judicial Advisor in the simplified bankruptcy consumer procedures and enforcement procedures. Full analysis would imply a different view on the role of the state, courts, European law and the analysis of Croatian judicial system, which is currently too complex to research within the scope of this paper. ${ }^{1}$ Nevertheless, based on the above-mentioned considerations, and the complexity of the thesis, authors will focus on a specific issue of the subject matter.

\section{MAIN DEFINITIONS OF TERMS}

Taking into consideration complexity of research thesis, it's important to define the following concepts: tribunal/court established by law, Judicial Advisor, simplified bankruptcy consumer procedure and enforcement procedure.

The European Convention for Human Rights and Fundamental Freedoms (Convention) is a "living instrument" ${ }^{2}$ which means that it is evolving through the case law of the ECHR. Hence, the meaning of the concept of tribunal is likewise evolving through the case law according to Article 6. However, the concept of an independent and impartial tribunal is well established in ECHR case law. The term tribunal means not only a body which exercises judicial power in a country (see Article 2 of the Law of Courts: LC) ${ }^{3}$, but also a body that can decide on matters within its competence and as prescribed by law. A tribunal must also satisfy a series of further requirements as e.g. independence and impartiality. In determining whether a body can be independent, ECHR has regarded several considerations such as the manner of appointment of court members and the duration of their terms in office, the existence of guarantees against outside pressures and the question of whether the body gives an appearance of independence. ${ }^{4}$

1 E.g. Many unresolved land registration cases, that led to the overload of courts, legislator tried to solve by appropriate legislative interventions. Therefore, the Act on Amendments to the Land Registration Act of 2004 introduced into the Croatian legal system land registration referents, as a new type of land registry officers. Certain jurisdictional powers in solving land registration cases were assigned to them. In accordance with the amendments of the Enforcement Act from 2012, Financial Agency (FINA) had a new role in out of courts debt enforcement. Furthermore, with the entry into force of the Inheritance Act, legislator tried to prevent overload of the courts, by delegating to public notaries inheritance proceedings. Moreover, Act on Amendments to the Enforcement Act in 2003 implemented possibility of conducting enforcement procedure by public notaries based on trustworthy documents

2 Narodne novine - Međunarodni ugovori, br. 18/97, 6/99, 14/02, 13/03, 9/05, 1/06, 2/10

3 Official Gazette, No. 28/13, 33/15, 82/15, 82/16, 67/18

4 Belilos v. Switzerland, 10 EHRR 466 (1988) 
Judicial Advisors' deontology emphasises that they are an institution that has been operating since 1946. Their function was designed to train and to enable them to serve as future judges. ${ }^{5}$ Current trends point to the practical equalization of the function of judges and Judicial Advisors. Namely, the novelty in LC introduced changes in that direction. Article 109 of LC states (1) Courts may employ Advisers and Senior Judicial Advisors and Senior Judicial Advisors - specialists. (2) A person who has graduated from a faculty of law and has passed the bar examination may be admitted as a Judicial Advisor ... Thus, this article implements a third type of court clerk into the existing system of Judicial Advisors, namely, the Senior Judicial Advisors-specialists. The powers of Judicial Advisors, Senior Judicial Advisors and Senior Judicial Advisors-specialists are also redefined. LC brings the possibilities for their independent undertaking of certain actions in court proceedings depending on their complexity, types of proceedings or the value of the case in dispute (Art. 110). ${ }^{6}$ However, the powers of Judicial Advisors in non-litigious proceedings under the $\mathrm{LC}$ are different so it is the doctrine that indicates whether or not Judicial Advisors should be allowed to make independent decisions in the non-litigious proceedings they conduct. ${ }^{7}$ This is interesting given that some special legal regulations prescribe the full independence of Judicial Advisors. For example, the Consumer Bankruptcy Act (hereinafter: $\mathrm{CBA})^{8}$ states that advisers are authorized to conduct a simplified consumer bankruptcy procedure and render decisions (Article 79). ${ }^{9}$ The draft of the Enforcement Act (EA) ${ }^{10}$ stipulates that in the first and second instance of the enforcement proceedings and insurance proceedings, an individual judge or the Judicial Advisor conduct the proceedings, if this law does not specify that the proceedings are conducted by a public notary.

In the implementation of a simplified consumer bankruptcy procedure, results suggested that the legal position of indebted consumers has not changed significantly, indicating that the implementation of the consumer bankruptcy procedure since 2016 has had no real results. Thus, Croatian government in its program for

5 See, Zuglia, S., Sudovi i ostali organi koji učestvuju u vršenju gradanskog pravosuđa, Školska knjiga, Zagreb, 1956, p. 100-101

6 Judicial Advisers and Senior Judicial Advisers and Senior Judicial Advisers - specialists are authorized to act and make decisions in certain procedures when it is prescribed by special laws (art. 110 (6) Law of the Courts)

7 See, Maganić, A., Novi pravci reforme izvanparničnog prava u Republici Hrvatskoj, Zbornik Aktualnosti građanskog procesnog prava - nacionalna i usporedna pravno teorijska i praktična dostignuća, 2015, p. $147-172$

8 Official Gazette, No. 100/15, 67/18

9 BA (Official Gazette, No 71/15, 104/17) has similar provisions. It states that judicial advisors are authorized to conduct shortened bankruptcy proceedings and bring decisions, except for the decision according to Article 433. (Art. 435(1))

10 See: [https://esavjetovanja.gov.hr/ECon/MainScreen ?entityId=9961] Accessed 02.03.2019 
period from 2016 to 2020, proposed to partially solve the problem of indebted citizens. For this reason, amendments of CBA were adopted. ${ }^{11}$ The most important novelty is a new section IX a "Simplified consumer bankruptcy procedure" (Art. 79 to $79 \mathrm{v}$ ) where terms and conditions of conducting simplified consumer bankruptcy procedure are defined, with the purpose of releasing debts for larger number of persons. The legislator has applied the principle of proportionality because there is a legitimate aim pursued in a public interest. That is a necessary, appropriate and proportionate measure taken against excessive burden of the addressees. In principle, opening of a bankruptcy procedure is only possible if certain legal assumptions are met. We must point out that the ECHR case law according to Article $6^{12}$ applies to bankruptcy procedures. ${ }^{13}$

Enforcement procedure has wide connotation and implementation. Standards of fair trial set out in Article 6 guarantee effective legal protection. So, in civil proceedings there must be an effective system of decisions enforcement. ${ }^{14}$ However, in the enforcement proceedings, the civil rights and obligations are not determined, they are enforced. This is a procedure conducted by the courts and notaries according to the EA, ${ }^{15}$ and has the purpose of forcible settlement of the creditor's claims on the assets of the debtor. It also regulates judicial and notarial securities based on an agreement of the parties and securities by compulsory creation of the right. However, enforcement procedure, along with the basic regulation, EA, is also regulated by other lex specialis laws. Aforementioned Enforcement act on monetary assets constitutes a legal framework for out-of-court enforcement conducted by FINA. According to the provisions of the General Taxation Act ${ }^{16}$,

11 Official Gazette, No 100/15, 67/18. The reform was multilateral and encompassed multiple regulations, new Law on the debts write-off to physical persons (Official Gazette, No 62/18.) and new Enforcement Act on monetary assets (Official Gazette, No 68/18.)

12 In the determination of his civil rights and obligations or of any criminal charge against him, everyone is entitled to a fair and public hearing within a reasonable time by an independent and impartial tribunal established by law. Judgment shall be pronounced publicly but the press and public may be excluded from all or part of the trial in the interests of morals, public order or national security in a democratic society, where the interests of juveniles or the protection of the private life of the parties so require, or to the extent strictly necessary in the opinion of the court in special circumstances where publicity would prejudice the interests of justice

13 Arg., S.p.r.l. ANCA and Others v Belgium (1984) Decisions and Reports 40, Interfina and Christian della Faille d'Huysse v Belgium (1987), unreported, Ceteroni v Italy, (1996), Reports of Judgments and Decisions 1996-V, Capital Bank AD v Bulgaria (2005) Capital Bank AD v Bulgaria (2005) 44 EHRR 48 and Sukobljević v. Croatia, (2006), 27 EHRR 249

14 Uzelac, A., Kako organizirati efikasno izvršenje nespornih tražbina - neka komparativna iskustva, Zbornik Konferencije "Kako unaprijediti izvršni postupak u BiH”, Sarajevo, 2009., [ww.hjpc.ba/pr/msword / PR0Alan Uzelac.doc] Accessed 12.02.2019

15 Official Gazette, No 112/12, 25/13, 93/14, 55/16, 73/17

16 Official Gazette, No 115/16, 106/18 
enforcement proceedings are part of a tax-legal relation in which a tax body carries out the procedure of compulsory collection of tax debt based on enforceable and trustworthy documents. Likewise, the Law on collection of tax debt from natural persons ${ }^{17}$ regulates the conditions and procedure of compulsory collection of the unpaid tax debt of a natural persons based on taxes, contributions and other public grants.

\section{FRAMEWORK FOR DISCUSSION}

Authors state that the role of the court in the Law on Forced Settlement, Bankruptcy and Liquidation (hereinafter: LFSBL) was undisputable in terms of its right to oblige all parties to the proceedings by its decisions, and in controlling legitimacy of procedure. ${ }^{18}$ So, the court conducted the proceedings and had a supervisory, control function when deciding about the merits of the case. The insolvent debtor could, before bankruptcy procedure was initiated, and during bankruptcy procedure, propose creditors to conclude a forced settlement to avoid bankruptcy liquidation. Nevertheless, the Law was applied in the "atmosphere" where some of the questions of legal and economic life were regulated outside the law. Also, the bankruptcy regulations have often had the function of implementing political decisions. The principles of bankruptcy procedure were redefined by BA from 1997. ${ }^{19}$ The bankruptcy procedure remained a judicial procedure that was conducted in accordance with the rules of non-litigious proceedings. Furthermore, bankruptcy procedure, unlike the other judicial procedures that are conducted exclusively by court bodies, also includes non-court bodies. Court bodies were Bankruptcy Council (abolished in 2003) ${ }^{20}$ and later Bankruptcy Judges as single judges. Non-court bodies were, and still are, Bankruptcy Trustee, Assembly of Creditors and Creditors' Committee. In relation to the LFSBL, Bankruptcy Council or Bankruptcy Judge had greater responsibility, given that the number of functions in the proceedings has also increased. To sum up, an important role of the court has been retained. The court rendered decision on commencement of bankruptcy procedure, appointed Temporary Bankruptcy Trustee and Bankruptcy Trustee. Furthermore, the court approved payment of creditors and rendered decisions on ending of bankruptcy proceedings. In addition, the court analysed the economic and financial situation of the debtor deciding whether there is a possibility for opening a bankruptcy procedure. It also made decisions on the amount of cost and rewards in bankruptcy procedure, to which the experts, the Temporary

\footnotetext{
17 Official Gazette, No 55/13

18 Official Gazette, No 53/91, 9/94, 54/94

19 Official Gazette, No 44/96, 29/99, 129/00, 123/03, 82/06, 116/10, 25/12, 133/12

20 Official Gazette, No 123/03
} 
Bankruptcy trustee, the Bankruptcy Trustee and the members of the Committee of Creditors were entitled. It also decided on complaints, supervised the operational implementation of bankruptcy procedure, and the work of the Bankruptcy Trustee. In doing so, it controlled the filing of the creditor's claims, monetization, keeping and forming of the bankruptcy estate and potential settlement of the creditors. In other words, the Bankruptcy Council or Bankruptcy Judge decided on all matters of bankruptcy procedure, except for those that are entrusted, according to law, to other bankruptcy body. We can state that the Bankruptcy Judges conducted and supervised the entire bankruptcy procedure as well as that their duties varied because they, apart from rendering decisions in bankruptcy procedure, also coordinated individual bodies of bankruptcy proceedings. The scope of his responsibility derives from this. In 1996, a process of reorganization was implemented as one of the possible ways of conducting bankruptcy procedure and was the only alternative to liquidation bankruptcy. The new BA in $2000^{21}$ has replaced reorganization by a wider and more precise legal technical term, bankruptcy plan. The court had the power to create, adopt, supervise and fulfil the plan. The Act on Financial Operations and Pre-Bankruptcy Settlement (hereinafter: $\mathrm{AFOBS})^{22}$ has been implemented not only because of the existing implementation of BA that led to evanesce of the legal person, but also because there is a tendency towards the USA model of pre-negotiated bankruptcy of a debtor prescribed in Chapter 11 of US Bankruptcy Code. The aim is to provide the possibility to the debtor to restructure and resume with its operations. The fundamental difference between BA and AFOBS was reflected in the authorised bodies that were conducting this procedure. Croatian legislator has decided to delegate the pre-bankruptcy settlement procedure to a legal person with public authority, Financial Agency (FINA), rather than to the courts. That is a precedent in the entire Croatian history concerning bankruptcy procedures since $1840 .{ }^{23}$ With the implementation of the AFOBS, the bankruptcy procedure in the Republic of Croatia has been substantially altered and there were lots of deficiencies. That was resolved by the adoption of the latest BA 2015. ${ }^{24}$ The most important novelties are articles of Chapter II (Art. 21 to 74), according to which the provisions on the pre-bankruptcy settlement are transferred from the AFOBS to the BA as a pre-bankruptcy procedure, according to which FINA is the body of the pre-bankruptcy procedure

\footnotetext{
$21 \quad$ Official Gazette, No 129/00

22 Official Gazette, No 108/12, 144/12, 81/13, 112/13, 71/15, 78/15

23 Garašić, J., Stečajni plan nakon izmjena i dopuna Stečajnog zakona 2012., in: Djelotvorna pravna zaštita u parničnom postupku, izazovi pravosudnih transformacija na jugu Europe, Zbornik radova u čast prof. dr. sc. Mihajla Dike, Pravni fakultet, Zagreb, 2013, p. 479

24 Official Gazette, No 71/15
} 
but can only technically and administratively assist the court. ${ }^{25}$ Thus, the body of pre-bankruptcy procedure is now a Tingle Judge and a Trustee (Art. 21) not the Settlement Council and a Trustee of pre-bankruptcy settlement (Art. 32 AFOBS). The pressure to reform the pre-bankruptcy settlement and to strengthen the role of the court, was intensified by the implementation of Art. 6 of the Convention and ECHR case law. Furthermore, the ECHR case law indicates that Art. 6 applies to bankruptcy procedures. ${ }^{26}$ The first question from above mentioned discussion is the legitimacy of the de-judicialization process through the model of the pre-bankruptcy settlement because the bankruptcy-legal protection must be within the competence of the body defined by the Convention as a "tribunal". ${ }^{27}$ Presently, only the court has those features. For this reason, the provisions which prescribed that FINA de facto and de jure decided in the pre-bankruptcy settlement procedure were deleted. According to the new provisions an independence of the court is crucial, and it is exercised by judges as a body of a state authority through the special rules of procedure. FINA has only auxiliary functions in the procedure. CBA was implemented in 2015 on financial recovery postulates. In the institute of bankruptcy plan and pre-bankruptcy procedure, as an alternative to liquidation bankruptcy, we observe certain similarities with the institute of bankruptcy against consumer's property as they all try to achieve the "economic recovery" of the debtor (Article 2). However, the fact that the proceedings are brought into the jurisdiction of municipal (Article 21(1)) and not commercial courts, that traditionally conducted this type of proceedings, may be indicative since it is questionable whether courts, which are not specialized in this type of cases, can conduct these cases adequately. The need for specialization of the courts results from the need for effective judicial protection in bankruptcy procedure. There is a difference between the aims of a consumer and a corporate bankruptcy. Differntia specifica of consumer bankruptcy resulted in the courts greater discretional powers. Exempli causa, without analysing the institute of "right to home" since the topic is too complex and institutionally sensible, authors point out that the court may, due to a request of the debtor and under certain conditions, delay the sale of debtor's home that is necessary for his habitation during a period of verification of his good behaviour (Art. 64). This allows the courts to legitimately formulate social policy when they're deciding on the matters of the case. In doing so they are not only deciding on legal matters because it is their aim to create a certain social policy through which they can engage more people than that is the case in dealing with an individual case (so-called, judicial activism). With the exception of the

\footnotetext{
25 It should be noted that the role of the Commercial court in the pre-bankruptcy settlement procedure is described in Art. 66 of AFOBS, which has been emended three times

26 Ismeta Bačić v. Croatia, No. 43595/06 (2008)

27 H. v. Belgium 10 EHRR 339 (1987)
} 
AFOBS and the fact that there are wide variations in professional standards of the organization of courts and judicial procedure, authors point that the legal standard of judicial jurisdiction in the general enforcement procedure is the result of an aspiration to achieve fairness in pursuit of accomplishing the purpose of bankruptcy procedure and realization of the principle of the equality of creditors, relativized by the existence of payment orders.

Currently, the EA requires that the enforcement procedure and the insurance procedure is conducted in the first instance by a single judge who also renders decisions, if it is not determined by the EA that the procedure is conducted, and decisions are rendered by a public notary. When the new EA entered into force, Article 10 corresponded to Article 10 of the EA from 1996. Significant changes were made only in the amendments of the EA in 2014 but were soon repealed. According to the amendments of 2017, the provisions that regulate decision making of council of three judges at first instance court, and a body that decides in a role of second instance body against certain appeals in an enforcement procedure, were also repealed. The above-mentioned regulation proved to be ineffective in practice, especially in courts where only a few judges decides. Besides, it has led to an unequal deciding on appeals. So, instead of the Council of the first instance court, the appeal proceedings are conducted, and decisions rendered by the Single Judge of the second instance court. However, the proposal of the draft of EA in 2019 redefines the above-mentioned provisions by determining that in the first and second instance of the enforcement procedure and the insurance procedure decisions should be rendered by a Single judges or Judicial Advisors, unless this Act determines that the procedure is conducted by a public notary (Article 11). A relatively broad scope of Judicial Advisor's jurisdiction leads to the questions about the constitutionality of the aforementioned provisions.

\section{SETTING UP THE THESIS}

By regulating that a simplified consumer bankruptcy procedure as well as enforcement procedure (draft) is placed under the jurisdiction of Judicial Advisors who are civil servants, ${ }^{28}$ not judges, the party to the proceeding is denied the right to a tribunal established by the law, the right to a fair trial and right to equal protection guaranteed by the Constitution and Convention. In the opinion of the authors, this constitutional guarantee excludes the possibility that a Judicial Advisor can independently conducts a proceeding and renders a decision in the determination of the rights and obligations of the parties. Also, the tribunal is characterised not only in the substantive sense by its judicial functions, but also as to its member-

28 Ordinance on Judicial Officers and Employees, Official Gazette, No 55/01, 156/04 
ship. ${ }^{29}$ So, although there are many similarities but also a significant difference between the function of judges and Judicial Advisors, primarily in the criteria of independence and impartiality, it is crucial that Judicial Advisors are not part of the judicial authority.

\section{LEGAL SOURCES RELEVANT TO THE SUBJECT MATTER}

The Constitution of Republic of Croatia ${ }^{30}$ states that everyone is entitled to a fair and public hearing within a reasonable time by an independent and impartial tribunal established by law in determination of his rights ... (Art 29(1)). Furthermore, the judiciary is performed by the courts (Article 115(1)), and the judicial duty is entrusted to the judges themselves. Judicial Advisors and jurors are conducting the trial according to the Law (Article 118). The doctrine indicates that although this provision provides the constitutional position of Judicial Advisors, the explanation of this is legally confusing. Nothing has been said about the status of a Judicial Advisors and why Judicial Advisors are participant in the court proceedings. It is not clear why are Judicial Advisors and jury in the same provision, when it comes to clerks who have a completely different role in the procedure and, furthermore, perform different tasks that are defined by completely different laws. ${ }^{31}$ Furthermore, by its decision from $13^{\text {th }}$ December 2016, the Constitutional Court did not accept the proposal to initiate proceedings for review the constitutionality of Article 13 of Civil Procedure Act because it concluded that that the disputed article does not give the Judicial Advisors the power to take a decision or, as the proposer wrongly stated, the power to adjudicate. Furthermore, Constitutional Court stated that decision-making must be independent process no matter if it is conducted by a judge or Judicial Advisor performing a duty of and for a judge..$^{32}$ Also, there is another case where the Constitutional Court has decided on the constitutionality of the participation of a Judicial Advisor in the enforcement procedure, concluding correctly that the adoption of the constitutional complaint in the present case would open Pandora's box of constitutionality of all decisions made in the procedures conducted by the Judicial Advisors. ${ }^{33}$ Civil proceedings are the basic system of providing legal protection in civil court proceedings, which is generally applied, whenever there is no non-litigious procedure based on the

\footnotetext{
29 Buscarini v San Marino ECHR, (dec.) (2000)

30 Official Gazette, No 56/90, 135/97, 08/98, 113/00, 124/00, 28/01, 41/01, 55/01, 76/10, 85/10, $05 / 14$

31 Maganić, A., Hraste, L., Razliciti oblici rasterećenja pravosuda u Republici Hrvatskoj - trebaju li Hrvatskoj Rechtspflegeri?, Pravnik, vol. 46, 2013., No. 1, p. 36-37

32 Constitutional Court of Croatia, decision, no. U-I-2191/2005, $13^{\text {th }}$ December 2016

33 Constitutional Court of Croatia, decision, no. U-III/998/2009, from $19^{\text {th }}$ March 2009
} 
explicit legal regulation. In the pre-bankruptcy, bankruptcy and enforcement procedures, the rules of civil procedure are applied (Article $10 \mathrm{BA}$, Article $21 \mathrm{EA}$ ). However, the bankruptcy and enforcement proceedings are sui generis non-litigious procedures. In addition, Civil Procedure $\mathrm{Act}^{34}$ states in Article 13(1) that Judicial Advisors are authorized in the first instance to conduct civil proceedings, to assess the evidence and to establish the facts. The Judicial Advisor shall submit to the judge, who is authorized by the president of the court, a written proposal based on which the judge shall render a decision. In the introduction of the decision it shall be stated that the decision was rendered on the proposal by a Judicial Advisor. (2) if the proposal given by the Judicial Advisor is not accepted, the competent judge shall conduct proceedings himself. (3) Judicial Advisors are authorized in civil proceedings to conduct proceedings and propose a decision to the judge in disputes for the payment of monetary claims, if the value of the subject of the dispute does not exceed 50,000.00 HRK, or in commercial disputes if the value of the subject of the dispute does not exceed 500,000.00 HRK. (4) In second instance proceedings and proceedings conducted upon extraordinary legal remedies, Judicial Advisors shall report on the state of the case file and prepare a draft of the decision. Assuming that the number of proceedings in which dissatisfied judges don't accept the drafts of the decision issued by Judicial Advisor and independently conduct the proceedings, is equal to zero or ultimately very low and, that at the same time Judicial Advisors take part in the conducting of a large number of small value dispute proceedings, authors reach the conclusion that the work of Judicial Advisors in reality is fully in line with the work and powers of judges, although their position in the judiciary system is fundamentally different from the position of a judge. ${ }^{35}$ Nevertheless, from the legislator's point of view this is a legitimate way of ensuring efficient use of judicial potential, while the regularity of a such procedure is guaranteed, in the proceedings conducted by the supervisory of the competent judge. ${ }^{36}$ An interesting situation is when person who did not have the status of a judge took part in the rendering of the judgment (Art. $354(2)(1)$ ). The court of second instance is paying attention to the substantial violations of civil procedure rules within the limits of the grounds specified in the appeal of the party (Art. 365(2)). In Croatia's procedural legal doctrine, in the situation where in decision making process is participating a person who is not a

34 Official Gazette, No 53/91, 91/92, 58/93, 112/99, 88/01, 117/03, 88/05, 02/07, 84/08, 96/08, 123/08, 57/11, 148/11, 25/13, 89/14 hereinafter: CPA

35 See, Jelinić, Z., O nedostacima i održivosti postojecíh pravila o vrijednosti predmeta spora u hrvatskom gradanskom procesnom pravu, Zbornik Aktualnosti gradanskog procesnog prava - nacionalna i usporedna pravno teorijska i praktična dostignuća, Pravni fakultet, Split, 2017, p. 225

36 Explanation of the Final Proposal of the Law on Amendments to the Civil Procedure Act,2013, [http:// www.sabor.hr, PZ_216.pdf] Accessed 12.02.2019, p. 24 
judge (e.g. Judicial Advisor) that decision is de facto non-existent. However, the CPA does not contain provisions on a non-existent judgement, which contributes to the formation of various legal arguments about what act might be submitted under the theoretical notion of a non-existent judgement. In addition, Dika noticed different situations, which accordingly could have different consequences. He also points out the situation where a Judicial Advisor participated in the decision-making process, while distinguishing the situations when the Judicial Advisor rendered a decision and signed it in this capacity (so the parties would be familiar with that circumstance) and, if a Judicial Advisor signed his decision by declaring himself as the judge. As to the first type of decision, parties could lodge a complaint, revision or a motion for a retrial. When there is no more possibility of lodging of such remedies (exempli causa, because of the expiration of deadlines for submitting a legal remedy) this decision still can be treated as being non-existent, or as one that can never be legally effective. With regard to the second situation, when the Judicial Advisor rendered a decision as a judge or declaring himself as a judge signing the decision, then that is a forgery, an act that should be treated equally as other out-of-court forgeries. ${ }^{37}$ In this context, the issue of legal certainty for the parties is raised in terms of providing quality legal protection against the acts that claim to be judicial decisions, and de facto are not. Nevertheless, the Croatian Supreme Court has decided even before the Amendments to the CPA in 2003 that the Croatian proceeding system doesn't have theoretical constructions of the non-existent decision and that participation in the proceedings of a person who doesn't have the capacity of a judge means the substantive violation of civil procedure. ${ }^{38}$ Failure to prescribe a notion of a non-existent decision and a failure by the party under the positive law regulations to fail a complaint because of the substantive violation of civil procedure, would have the effect of the finality of the decision and thus granting legal effect to the decision rendered by a person that is not a judge or where such person has conducted the proceedings contrary to the Constitution and laws of state. ${ }^{39}$ The provisions of LC, that have entered into force at the beginning of the year, states, as mentioned above, introduced into the existing system of Judicial Advisors, Judicial Advisors - specialists. The reason for the introduction of new type of Judicial Advisors lies in the effort to separate the

37 See, Triva, S.; Dika, M., Gradansko parnično procesno pravo, Narodne novine, Zagreb, 2004, p. 134137; Triva, S.; Belajec, V.; Dika, M., Gradansko parnično procesno pravo, Narodne novine, Zagreb, 1986, p. 564-565

38 Supreme Court of the Republic of Croatia, Gž 1738/79 - PSP 16/197 a case conducted by an asociate. Source: Tironi, I.; Tironi, Z., Bitne povrede odredaba zakona o parničnom postupku i nacrt novele iz 2018., Zbornik radova s IV. međunarodnog savjetovanja Aktualnosti građanskog procesnog prava nacionalna i usporedna pravnoteorijska i praktična dostignuća, Pravni fakultet, Split, 2018, p. 351-355

39 Triva; Dika, op. cit., note 35, p. 690-691 
powers of Judicial Advisors and to create a special system of the promotion of these officials, who under the Constitution of the Republic of Croatia, participate in the proceedings. Article 109(3)(4) of LC, that is not in force, stated that function of Judicial Advisors can also perform state attorney's adviser who has not been, until recently, covered by these provisions. It also prescribes powers of Judicial Advisors, Senior Judicial Advisors and Senior Judicial Advisors - specialists, by enabling the possibilities for their independent undertaking of certain actions in court proceedings according to their complexity, types of proceedings or the value of the subject matter of the dispute. The position of Judicial Advisors is thus strengthened by the expansion of their existing powers. However, the provision of Article 110(5), which is disputable, explicitly stipulates that Judicial Advisors and Senior Judicial Advisors are authorized to conduct the proceedings and render the decisions in specific proceedings when it is prescribed by special laws, e.g. EA (draft) of CBA.

From the perspective of European law, accepting the fact that case law of the ECHR affirms the principle of precedent and thus the case law as a formal source of law, authors point out the importance of judgment of Ezgeta $v$ Croatia..$^{40}$ The applicant complained that the judgement in the civil proceedings violates Article 6, because it was rendered by Judicial Advisor who had not been authorised to do so under the relevant domestic law. The ECHR found a violation of the right to a fair trial, stating that the composition of the court in each case should be in accordance with the law. Considering that Judicial Advisors, according to the positive laws of the Republic of Croatia, were not authorized to conduct the procedure, ECHR found a violation of Article 6, because the judgment in the domestic proceedings was not rendered by a court established by law. Furthermore, as there are no EU directives and regulations on the issue, the relevant standards are based on various acts adopted by the United Nations and relevant Council of Europe bodies, such as the Council of Ministers and the Council of Europe Judges (CCJE), as well as the Venice Commission. The Venice Commission has concluded that the standards in this area are outnumbered. This guarantee should be understood as a system that ensures a balance between the state authorities and prevents misreading and / or misuse of the concept of judicial independence.

Furthermore, if a comparative legal method is a necessary for mutual dialogue and harmonization of national systems we must also consider case law of other EU member states. Exempli causa, the Supreme Court of Iceland found unconstitutional and contrary to the Convention case on participation of Icelandic Judicial Advisors, who were co-operating with the judges in preparing for a future career

$40 \quad$ ECHR, Case no. 40562/12 (2017) 
as judges, but in practice began to do the same work as judges, in spite of the fact that they are not independent as judges and that they are under the jurisdiction of the Ministry of Justice that may indirectly or directly influence their action. Such practice, which is very similar to the current Croatian practice, was found to be a violation of the right to a fair trial. ${ }^{41}$

\section{CONCLUSION REMARKS}

The issues of the enforcement procedure and the consumer bankruptcy procedure in the Croatian legal system are complex from both theoretical and legal point of view. It is also a complex decision-making process of the most important rights and legally recognized interests of the persons involved. However, according to nomothetic rules and certain legislative solutions, authors point out a legally questionable solution according to the Constitution and ECHR that authorize Judicial Advisors to conduct enforcement procedure and simplified consumer bankruptcy procedure. So, deciding whether Judicial Advisors are authorised or not to conduct enforcement procedure and simplified consumer bankruptcy procedure, is problematic, because the coexistence of these two standpoints is not possible and one would have to replace the other. In principle, in Croatian legal system such regulation is justified, but the authors will, nevertheless, support the thesis that Judicial Advisors do not have, from the perspective of constitutional and convention laws, the right to independently conduct the proceedings and to render decisions. Bearing in mind the complexity of this thesis and accepting the fact that there are arguments pro et contra, we conclude that ultimately the decision depends on the "weights" attributed to one or the other group of arguments, and that "weight" could also be questionable. Deciding on this matter could be explained through the following argumentation. Consumer bankruptcy does not have a long legal tradition, so at the institutional level it is necessary that the courts (judges) resolve the legal conflicts. Moreover, the EA from 1996 has been changed almost every two years, so it is also difficult for experienced judges to determine which rules are applied in each and particular case. However, judges by their interpretation and application of the rights to a particular case contribute to the shaping of new views on these complex legal instruments. With such extension of the rights of Judicial Advisors, independence of the judiciary becomes improperly interpreted. So, a dissemination of judicial independence to the position of Judicial Advisors, that is by its own very nature and its role different from the judiciary, results in a sort

${ }_{41}$ Uzelac, A., Pravo na pravično sudenje u gradanskim stvarima: nova praksa Europskog suda za ljudska prava i njen utjecaj na hrvatsko pravo i praksu, Zbornik Pravnog fakulteta u Zagrebu, vol. 60, No. 1, 2010, p. 24 
of judicial corporatization with predominantly quantitative instead of qualitative decision-making process.

\section{REFERENCES}

\section{BOOKS AND ARTICLES}

1. Garašić, J., Stečajni plan nakon izmjena i dopuna Stečajnog zakona 2012., in: Djelotvorna pravna zaštita u parničnom postupku, izazovi pravosudnih transformacija na jugu Europe, Zbornik radova u čast prof. dr. sc. Mihajla Dike, Pravni fakultet, Zagreb, 2013, p. 479

2. Jelinić, Z., O nedostacima i održivosti postojećih pravila o vrijednosti predmeta spora u hrvatskom gradanskom procesnom pravu, Zbornik Aktualnosti građanskog procesnog prava - nacionalna i usporedna pravno teorijska i praktična dostignuća, Pravni fakultet, Split, 2017, p. 225

3. Maganić, A., Novi pravci reforme izvanparničnog prava u Republici Hrvatskoj, Zbornik Aktualnosti građanskog procesnog prava - nacionalna i usporedna pravno teorijska i praktična dostignuća, 2015, p. 147-172

4. Maganić, A.; Hraste, L., Različiti oblici rasterećenja pravosuda u Republici Hrvatskoj - trebaju li Hrvatskoj Rechtspflegeri?, Pravnik, vol. 46, 2013., No. 1, p. 36-37

5. Tironi, I.; Tironi, Z., Bitne povrede odredaba zakona o parničnom postupku i nacrt novele iz 2018., Zbornik radova s IV. međunarodnog savjetovanja Aktualnosti građanskog procesnog prava - nacionalna i usporedna pravnoteorijska i praktična dostignuća, Pravni fakultet, Split, 2018, p. 351-355

6. Triva, S.; Dika, M., Gradansko parnično procesno pravo, Narodne novine, Zagreb, 2004, p. 134-137

7. Triva, S.; Belajec, V.; Dika, M., Gradansko parnično procesno pravo, Narodne novine, Zagreb, 1986, p. 564-565

8. Uzelac, A., Pravo na pravično sudenje u gradanskim stvarima: nova praksa Europskog suda za ljudska prava i njen utjecaj na hrvatsko pravo i praksu, Zbornik Pravnog fakulteta u Zagrebu, vol. 60, No. 1, 2010, p. 24

9. Zuglia, S., Sudovi i ostali organi koji učestvuju u vršenju gradanskog pravosuda, Školska knjiga, Zagreb, 1956, p. 100-101

\section{ECHR}

1. European Convention for protection of Human Rights and Fundamental Freedoms - Official Gazette, International Treaties, No 18/97, 6/99, 14/02, 13/03, 9/05, 1/06, 2/10

\section{JUDGMENTS AND DECISIONS}

1. Buscarini v San Marino ECHR, (dec.) (2000)

2. Capital Bank AD v Bulgaria (2005) 44 EHRR 48

3. Ceteroni v Italy, (1996), Reports of Judgments and Decisions 1996-V 
4. Ezgeta v Croatia, ECHR, Case no. 40562/12 (2017)

5. Interfina and Christian della Faille d'Huysse v Belgium (1987), unreported

6. S.p.r.l. ANCA and Others $v$ Belgium (1984) Decisions and Reports 40

7. Sukobljević v Croatia, (2006), 27 EHRR 249

\section{LIST OF NATIONAL REGULATIONS, ACTS AND COURT DECISIONS}

1. Constitution of Republic of Croatia, Official Gazette, No 56/90, 135/97, 08/98, 113/00, $124 / 00,28 / 01,41 / 01,55 / 01,76 / 10,85 / 10,05 / 14$

2. Law of Courts, Official Gazette, No. 28/13, 33/15, 82/15, 82/16, 67/18

3. Consumer Bankruptcy Act, Official Gazette, No. 100/15, 67/18

4. Bankruptcy Act, Official Gazette, No 71/15, 104/17

5. Law on the debts write-off to physical persons, Official Gazette, No 62/18

6. Enforcement Act on monetary assets, Official Gazette, No 68/18

7. Enforcement Act, Official Gazette, No 112/12, 25/13, 93/14, 55/16, 73/17

8. General Taxation Act, Official Gazette, No 115/16, 106/18

9. Law on Forced Settlement, Bankruptcy and Liquidation, Official Gazette, No 53/91, 9/94, $54 / 94$

10. Bankruptcy Act, Official Gazette, No 44/96, 29/99, 129/00, 123/03, 82/06, 116/10, 25/12, 133/12

11. Bankruptcy Act, Official Gazette, No $71 / 15$

12. Bankruptcy Act, Official Gazette, No 123/03

13. Bankruptcy Act, Official Gazette, No 129/00

14. Act on Financial Operations and Pre-Bankruptcy Settlement, Official Gazette, No 108/12, $144 / 12,81 / 13,112 / 13,71 / 15,78 / 15$

15. Civil Procedure Act, Official Gazette, No 53/91, 91/92, 58/93, 112/99, 88/01, 117/03, $88 / 05,02 / 07,84 / 08,96 / 08,123 / 08,57 / 11,148 / 11,25 / 13,89 / 14$

16. Ordinance on Judicial Officers and Employees, Official Gazette, No 55/01, 156/04

17. Constitutional Court of Croatia, decision, no. U-I-2191/2005, $13^{\text {th }}$ December 2016

18. Constitutional Court of Croatia, decision, no. U-III/998/2009, from $19^{\text {th }}$ March 2009

19. Supreme Court of the Republic of Croatia, Gž 1738/79 - PSP 16/197

\section{WEBSITE REFERENCES}

1. [https://esavjetovanja.gov.hr/ECon/MainScreen ?entityId=9961] Accessed 02.03.2019

2. Uzelac, A., Kako organizirati efikasno izvršenje nespornih tražbina - neka komparativna iskustva, Zbornik Konferencije "Kako unaprijediti izvršni postupak u BiH”, Sarajevo, 2009., [ww. hjpc.ba/pr/msword /PR0Alan Uzelac.doc] Accessed 12.02.2019

3. Explanation of the Final Proposal of the Law on Amendments to the Civil Procedure Act,2013, [http://www.sabor.hr, PZ_216.pdf] Accessed 12.02.2019, p. 24 